\title{
PERKAWINAN: ARTI PENTING, POLA DAN TIPE PENYESUAIAN ANTAR PASANGAN
}

Hepi Wahyuningsih

\begin{abstract}
Abstrak
Tulisan ini bermaksud membahas tentang pentingnya sebuah penyesuaian dalam perkawinan. Penyesuaian perkawinan merupakan hal yang penting dalam perkawinan karena suami istri memiliki karakter yang berbeda-beda. Penyesuaian yang gagal dapat berakhir dengan perceraian. Pasangan suami-istri akan menggunakan pola-pola penyesuaian yang mungkin berbeda antara pasangan suami-istri yang satu dengan yang lainnya. Adapun pola-pola penyesuaian yang biasa digunakan oleh pasangan suami-istri dapat dibedakan menjadi tiga, yaitu: kompromi, akomodasi, dan permusuhan. Ada lima tipe perkawinan berkaitan dengan penyesuaian perkawinan yang dilakukan pasangan suami-istri, yaitu: conflict-habituated relationships, devitalized relationships, passive-congenital relationships, vital relationships, dan total relationships.
\end{abstract}

Kata-kata kunci : penyesuaian, pola, tipe perkawinan

\section{PENDAHULUAN}

Krisis ekonomi yang berkepanjangan di Indonesia terjadi karena adanya krisis kualitas sumber daya manusia. Menurut Ancok (Kedaulatan Rakyat, 22 Januari 1993), krisis kualitas sumber daya manusia terjadi karena pembangunan yang hanya berorientasi pada pertumbuhan ekonomi. Lebih lanjut Ancok (Kedaulatan Rakyat, 22 Januari 1993) menjelaskan bahwa pembangunan yang hanya berorientasi pada pertumbuhan ekonomi menyebabkan terjadinya perubahan nilai hidup yang tertuju pada pengumpulan harta sebanyak-banyaknya (materialistik) demi tujuan kepuasan hidup sementara di dunia (hedonistik). Gaya hidup materialistik dan hedonistik menyebabkan orang berusaha keras untuk memperoleh harta, sehingga suami/istri bekerja keras di luar rumah mencari materi. Kondisi semacam ini dapat mengganggu hubungan suamiistri, yang pada akhirnya dapat mengakibatkan ketidakharmonisan dalam rumah tangga. Ketidakharmonisan dalam keluarga merupakan ancaman bagi upaya peningkatan kualitas manusia karena keluarga adalah lembaga pertama dan utama dalam pengembangan manusia yang berkualitas. Contoh ketidakharmonisan keluarga yang paling mudah dilihat adalah meningkatnya angka perceraian di kalangan selebritis. 
Berkaitan dengan masalah perceraian, sebenarnya perceraian merupakan hal yang dapat saja terjadi dalam sebuah perkawinan setelah semua cara yang ditempuh untuk menyelamatkan perkawinan tidak membuahkan hasil. Oleh karena itu, dalam Undang-Undang Perkawinan No. 1 tahun 1974 (Kowani, 1983) juga diatur masalah perceraian. Dalam salah satu hukum agama yang banyak dianut oleh penduduk Indonesia, yaitu agama Islam, juga disebutkan bahwa perkawinan merupakan suatu ikatan, dan ikatan itu harus diupayakan terjalin utuh, tetapi jika secara manusiawi hal tersebut menjadi mustahil, maka perceraian diizinkan oleh hukum agama (Doi, 1992).

Berdasarkan Undang-Undang Perkawinan No.1 tahun 1974 dan hukum Islam dapat ditarik kesimpulan bahwa perceraian merupakan alternatif terakhir yang dapat digunakan untuk menyelesaikan masalah perkawinan. Hal ini menunjukkan bahwa perceraian dapat menjadi salah satu cara yang terbaik untuk menyelamatkan setiap orang yang terlibat di dalamnya dari kondisi yang tidak menguntungkan bagi kesehatan mentalnya. Meskipun demikian, perceraian tetap merupakan sebuah permasalahan bila dikaitkan dengan tujuan perkawinan, karena terjadinya perceraian menunjukkan tidak tercapainya tujuan perkawinan.

Perceraian dapat disebabkan oleh beberapa faktor. Data yang diperoleh dari Pengadilan Agama yang ada di Yogyakarta menunjukkan bahwa ada dua faktor yang sering dilaporkan sebagai penyebab perceraian, yaitu (1) salah satu pasangan suami-istri me- ninggalkan kewajibannya, dan (2) pasangan suami-istri terus menerus berselisih. Kedua faktor penyebab perceraian tersebut sangat terkait dengan penyesuaian perkawinan. Kaitan antara dua faktor penyebab perceraian dengan penyesuaian perkawinan dapat dilihat dari pendapat Laswell \& Laswell (1987) bahwa konsep penyesuaian perkawinan mengandung dua pengertian yang tersirat.

Pengertian yang pertama, konsep penyesuaian perkawinan mengandung pengertian adanya hubungan mutualisme (saling menguntungkan) antara pasangan suami-istri untuk memberi dan menerima (menunaikan kewajiban dan menerima hak), sehingga jika salah satu dari pasangan suami-istri atau keduanya tidak menunaikan kewajiban maka tidak terjadi hubungan mutualisme, yang berarti tingkat penyesuaian perkawinannya rendah.

Pengertian yang kedua, konsep penyesuaian perkawinan juga secara tidak langsung menunjukkan adanya dua individu yang saling belajar untuk mengakomodasi kebutuhan, keinginan dan harapannya dengan kebutuhan, keinginan, dan harapan dari pasangannya, kemudian dalam proses pengakomodasian tersebut dapat terjadi perselisihan karena adanya ketidaksamaan kebutuhan, keinginan, dan harapan di antara pasangan suamiistri.

\section{PENGERTIAN PENYESUAIAN PERKAWINAN}

Schneiders (1955) menyatakan bahwa penyesuaian perkawinan adalah suatu seni dalam hidup yang 
terbingkai dalam kerangka tanggung jawab, hubungan, dan harapan yang merupakan hal-hal mendasar dalam perkawinan. Sebagai sebuah seni dari hidup, tidak salah bila Laswell \& Laswell (1987) menyatakan bahwa penyesuaian perkawinan adalah sebuah proses yang panjang karena setiap orang dapat berubah sehingga setiap waktu masing-masing pasangan harus melakukan penyesuaian perkawinan.

Sebagai sebuah proses, penyesuaian perkawinan dilihat oleh Burgess \& Cottrell (Klein, 2000) sebagai suatu proses akomodasi dan asimilasi. Penyesuaian perkawinan merupakan proses akomodasi karena dalam penyesuaian perkawinan masingmasing pasangan mengubah dirinya untuk menyesuaikan diri dengan pasangannya, sedang proses asimilasi berarti mengubah pasangannya agar sesuai dengan dirinya. Jadi masingmasing dari pasangan suami-istri selain melakukan perubahan pada dirinya, juga akan mengubah pasangannya.

Pendapat Burgess \& Cotrell tersebut sejalan dengan pendapat Hoult (Dyer, 1983) bahwa penyesuaian perkawinan merupakan perubahan sikap dan tingkah laku pada masing-masing pasangan suami-istri yang menguntungkan untuk memenuhi harapan atau tujuan perkawinan. Pendapat ini juga sejalan dengan pendapat LeMasters (Dyer, 1983) yang menyatakan bahwa penyesuaian perkawinan dapat didefinisikan sebagai kemampuan untuk melakukan penyesuaian atau kemampuan beradaptasi dan kemampuan memecahkan problem yang muncul dalam perkawinan.

Dyer (1983) menyatakan bah- wa banyak literatur mengenai penyesuaian perkawinan dikaitkan dengan kebahagiaan atau kepuasan perkawinan. Orang yang bahagia atau puas dengan perkawinannya dikatakan memiliki penyesuaian perkawinan yang baik, sedang orang yang tidak bahagia atau tidak puas dalam perkawinannya dikatakan memiliki penyesuaian perkawinan yang buruk. Pendapat Dyer ini sejalan dengan pendapat Graham dkk (2000) yang menyatakan bahwa penyesuaian perkawinan adalah pelaporan subyektif mengenai tingkat kepuasan berkaitan dengan bagaimana ia dapat berbagi minat, tujuan, nilai dan pandangan dalam hubungan perkawinannya.

\section{URGENSI PENYESUAIAN PERKAWINAN}

Sadli (BP4, 1991) menjelaskan bahwa perkawinan memiliki serangkaian ciri-ciri psikologis, salah satu di antaranya adalah bahwa kehidupan perkawinan menuntut pasangan suamiistri untuk menyesuaikan diri dengan pasangannya. Penyesuaian diri dengan pasangan (penyesuaian perkawinan) diperlukan dalam kehidupan perkawinan agar tercapai keharmonisan perkawinan, meskipun pasangan tersebut telah berpacaran sebelumnya.

Landis \& Landis (1963) berpendapat bahwa meskipun sebelum menikah pasangan telah berpacaran terlebih dahulu, ketika mereka telah melangsungkan pernikahan mereka tetap memerlukan penyesuaian perkawinan. Hal ini terjadi karena dua orang yang berpacaran mempunyai kecenderungan untuk lebih memperhatikan persamaan yang ada pada diri mereka dari 
pada perbedaan yang ada, sehingga mereka tidak banyak mempelajari perbedaan-perbedaan yang ada di antara mereka.

Menurut Kephart \& Jedlica (1991), jika proses pemilihan pasangan (berpacaran) merupakan sebuah proses yang efektif, maka penyesuaian perkawinan sudah tidak begitu dibutuhkan. Pada kenyataannya, orang yang sedang berpacaran baru mengetahui bagaimana harapan pacarnya dan bagaimana meraih cinta. Setelah menikah, baru mengetahui bahwa ada beberapa harapan yang disusun ketika berpacaran tidak dapat terpenuhi ketika sudah menikah. Sesudah menikah, kepribadian, harapan mengenai peran, dan keterlibatan dengan hal-hal di luar keluarga sering tidak sesuai dengan ketika berpacaran, sehingga sesudah menikah pasangan suamiistri membutuhkan kesepakatankesepakatan, komunikasi yang jelas, dan fleksibilitas untuk menyesuaikan diri dengan pasangan dan dunia di sekeliling mereka.

Seperti yang dikemukakan oleh Kephart \& Jedlica bahwa penyesuaian perkawinan dibutuhkan dalam perkawinan, Laswell \& Laswell (1987) menyatakan bahwa konsep penyesuaian perkawinan mengandung dua pengertian yang tersirat yang harus ada dalam perkawinan. Kedua pengertian tersebut adalah adanya hubungan mutualisme antara pasangan suami-istri dan adanya dua individu yang saling belajar untuk mengakomodasi kebutuhan, keinginan dan harapannya dengan kebutuhan, keinginan, dan harapan dari pasangannya.

Pernyataan Laswell \& Laswell tersebut di atas mengandung maksud bahwa hubungan yang seharusnya terjalin antara suami-istri adalah hubungan yang menguntungkan kedua belah pihak. Suami dan istri harus dapat menunaikan kewajibannya agar hubungan antar keduanya dapat saling menguntungkan. Hukum Islam menjelaskan bahwa jika akad nikah telah selesai diucapkan, maka akad tersebut akan menimbulkan kewajiban dan hak suami-istri (Sabiq, 1994). Kewajiban tersebut adalah sebagai konsekuensi logis dari berubahnya peran seseorang dari seorang bujangan menjadi seorang suami atau seorang istri. Dengan ditunaikannya kewajiban, hak pasangannya akan terpenuhi. Jika masingmasing telah mendapatkan haknya, maka tercipta hubungan yang saling menguntungkan.

Menurut Sabiq (1994), dalam hukum Islam, kewajiban dan hak suami istri ada tiga macam, yaitu hak istri atas suami (kewajiban suami), hak suami atas istri (kewajiban istri), dan hak bersama (kewajiban suami-istri). Syuqqoh (1999) menjelaskan bahwa kewajiban suami yang utama adalah memimpin rumah tangga dan memberi nafkah, sedangkan kewajiban istri yang utama adalah mengasuh anak dan mengatur urusan rumah tangga. Kemudian hak bersama suami-istri dapat dirinci menjadi sepuluh, yaitu: kelemahlembutan; kasih sayang; reproduksi; kepercayaan dan baik sangka; berpartisipasi dalam cita-cita dan berbagai urusan umum maupun khusus; berhias; bergaul dan melakukan hubungan biologis; memperoleh hiburan; cemburu; dan berpisah secara ma'ruf (baik). 
Syuqqoh (1999) menjelaskan bahwa dalam setiap kewajiban baik kewajiban suami atau kewajiban istri, suami-istri harus saling tolong menolong untuk menunaikan kewajibannya. Seorang istri menolong suami agar suaminya dapat menunaikan kewajibannya dan seorang suami menolong istri agar istrinya dapat menunaikan kewajibannya. Tolong menolong tersebut misalnya adalah suami membantu istri dalam mengasuh anak, suami membantu istri mengerjakan tugastugas rumah tangga, suami-istri bermusyawarah mengenai masalah yang penting dalam rumah tangga, istri taat pada suami, istri menggantikan posisi suami ketika suaminya pergi, atau istri bekerja untuk mencukupi kebutuhan rumah tangga dengan ijin suami.

Berkaitan dengan hak bersama suami istri, Syuqqoh (1999) menjelaskan bahwa hak-hak tersebut sekaligus juga kewajiban suami atau istri. Kesepuluh hak bersama suami istri yang telah disebutkan di atas mengandung maksud bahwa suami istri harus berusaha menyesuaikan diri dengan pasangannya. Hal ini menandakan bahwa suami dan istri, keduaduanya harus mampu mengakomodasi kebutuhan, keinginan dan harapannya dengan kebutuhan, keinginan, dan harapan dari pasangannya.

Pengertian di atas juga senada dengan penjelasan Erikson mengenai tahap-tahap perkembangan. Erikson (Papalia \& Old, 1995) menyatakan bahwa pada masa dewasa awal, seseorang harus dapat meraih intimacy. Intimacy dapat diraih dengan adanya komitmen untuk menjalin hubungan baik dengan pasangan yang memer- lukan pengorbanan dan kompromi dengan pasangan.

Menurut Hendrix (1997), penerapan konsep ini dalam perkawinan secara logika adalah bah'sa dalam perkawinan harus ada saling berbagi di antara pasangan suami istri, yang berarti ada pengorbanan dan kompromi. Jika tidak ada saling berbagi antara suami-istri, maka intimacytidak akan dapat berkembang. Dengan demikian dapat dikatakan bahwa menurut Erikson, dalam sebuah perkawinan, masing-masing dari pasangan suamiistri harus saling berbagi. Saling berbagi dapat diraih dengan melakukan pengorbanan dan melakukan kompromi. Hal ini menunjukkan bahwa dalam perkawinan, khususnya pada masa dewasa awal, masing-masing dari pasangan suami-istri harus melakukan penyesuaian perkawinan.

\section{HAL-HAL YANG PERLU DISESUAI- KAN DALAM PERKAWINAN}

Seseorang yang sudah menikah terikat oleh sebuah tanggungjawab. Orang tersebut harus berusaha agar perkawinannya bahagia. Bersamasama dengan pasangannya, perkawinan dibangun dengan dasar kerjasama yang baik dalam hal-hal yang mendasar. Menurut Landis \& Landis (1963), ada beberapa hal mendasar yang memerlukan kerjasama dan penyesuaian untuk membangun sebuah perkawinan, yaitu berkaitan dengan hubungan seksual, masalah keuangan, agama, aktivitas sosial \& rekreasi, hubungan dengan keluarga dari pasangannya, hubungan dengan teman, dan cara pengasuhan anak.

Seperti yang dikemukakan 
oleh Landis \& Landis, Syuqqoh (1999) mengemukakan bahwa dalam hukum Islam, ketika seseorang telah menikah ia terikat oleh tanggungjawab untuk menunaikan kewajibannya agar perkawinannya bahagia. Syuqqoh (1999) lebih lanjut mengemukakan bahwa untuk menunaikan kewajiban-kewajibannya, suami-istri perlu bekerjasama. Secara umum ada empat hal yang memerlukan kerjasama dalam penunaian kewajiban, yaitu dalam kaitannya dengan kepemimpinan suami (hal ini menunjukkan adanya kerjasama dalam hal-hal penting dalam perkawinan, seperti aktivitas keluarga), nafkah (keuangan), pengasuhan anak, dan urusan rumah tangga (pekerjaan rumah tangga). Glick (Hurlock, 1993) mengemukakan bahwa ada empat macam penyesuaian yang harus dilakukan oleh pasangan suami istri agar perkawinannya bahagia, yaitu: penyesuaian pasangan, penyesuaian seksual, penyesuaian keuangan, dan penyesuaian dengan keluarga pasangan.

\section{FAKTOR-FAKTOR YANG MEMPE- NGARUHI PENYESUAIAN PERKA- WINAN}

Penyesuaian perkawinan bukan merupakan sesuatu yang mudah. Holmes dan Rahe (Calhoun \& Acocella, 1990 ), dua orang yang membuat alat untuk mengukur tingkat stress, memberikan nilai 50 LCUs (Life Change Units) pada peristiwa perkawinan, nilai 45 LCUs pada peristiwa rekonsiliasi dalam perkawinan, dan nilai 35 LCUs pada peristiwa adu argumentasi dengan pasangan. Ketiga hal tersebut adalah hal-hal yang terkait dengan penyesuaian perkawinan, sehingga dengan melihat nilai LCU dari masingmasing peristiwa tersebut dapat dikatakan bahwa penyesuaian perkawinan memang merupakan hal yang cukup sulit.

Schneiders (1955) menyatakan bahwa penyesuaian dalam perkawinan memang bukan hal yang mudah. Lebih lanjut Schneiders (1955) menjelaskan bahwa setidaknya ada tiga penjelasan mengapa penyesuaian dalam perkawinan tidak mudah. Pertama, dalam perkawinan orang dituntut untuk terus menerus melakukan penyesuaian dengan pasangan hidupnya. Ketika seseorang merasa tidak cocok dengan seorang teman ia bisa meninggalkan teman tersebut dan bergabung dengan teman yang lain, tetapi ketika seseorang merasa tidak cocok dengan pasangannya ia tidak bisa begitu saja meninggalkan pasangannya. Kedua, dalam perkawinan orang dituntut untuk bertanggung jawab. Ketika seseorang merasa temannya mulai mengganggunya, ia tidak akan menemui teman tersebut untuk menurunkan kejengkelannya. Tetapi, jika yang menganggu adalah pasangannya, maka ia tidak dapat begitu saja menghindari pasangannya. la harus dapat memecahkan masalah tersebut. Ketiga, dalam perkawinan, hubungan emosional antara istri dengan suami mungkin akan terganggu dengan pertumbuhan keluarga.

Penyesuaian perkawinan juga bukan hal yang mudah karena dipengaruhi oleh banyak faktor. Misalnya, Burgess \& Colttrell (Klein, 2000) mengemukakan bahwa usia ketika menikah, hubungan dengan orangtua, kondisi perkawinan orangtua, kemampuan bersosialisasi, dan religiusitas 
merupakan faktor-faktor yang mempengaruhi tingkat penyesuaian perkawinan seseorang. Berkaitan dengan religiusitas, Landis \& Landis (1963) juga mengemukakan bahwa religiusitas memiliki peranan dalam perkawinan, termasuk dalam penyesuaian perkawinan.

Schneiders (1964) mengatakan bahwa beberapa faktor yang mempengaruhi penyesuaian perkawinan, sebagai berikut.

a. Tingkat penyesuaian suami atau istri sebelum menikah.

Maksud dari tingkat penyesuaian suami atau istri sebelum menikah adalah tingkat kematangan, tingkat kestabilan emosi, dan rasa aman yang dimiliki suami atau istri sebelum menikah. Hal-hal tersebut sangat dipengaruhi oleh latar belakang keluarga, pengasuhan orangtua, konflik dengan ibu, kedisiplinan yang diterapkan oleh orangtua, kelekatan pada ibu, kelekatan pada ayah, konflik dengan ayah, pendidikan seks, pemberian hukuman, dan sikap yang baik terhadap perilaku seksual. Orang yang memiliki tingkat penyesuaian yang baik akan bertanggung jawab untuk memelihara perkawinannya, sebaliknya orang yang memiliki tingkat penyesuaian yang rendah kurang bertanggung jawab dalam memelihara perkawinannya.

b. Sikap terhadap perkawinan.

Sikap setiap pasangan mengenai perkawinan akan berpengaruh pada penyesuaian perkawinan. Jika setiap pasangan memiliki sikap bahwa perkawinan adalah sebuah ikatan yang tidak gampang diputus, maka mereka akan bertanggung jawab untuk berusaha keras menjaga ikatan perkawinannya sehingga tingkat penyesuaian perkawinannya tinggi. Sebaliknya, jika setiap pasangan memiliki sikap bahwa ikatan perkawinan mudah untuk diputus maka mereka kurang bertanggung jawab untuk menjaga ikatan perkawinan, sehingga tingkat penyesuaian perkawinannya rendah.

c. Motivasi melakukan perkawinan. Motivasi untuk menikah dari setiap pasangan akan menyebabkan setiap pasangan berperilaku sesuai motivasi dia menikah. Jika motivasi menikah hanya untuk memenuhi kebutuhan biologis maka penyesuaian perkawinan tidak akan terjadi. Jika motivasi perkawinan karena perasaan cinta yang mendalam, keinginan memiliki orang yang dapat diajak berbagi suka duka, keinginan memiliki anak dan keluarga, maka penyesuaian perkawinan akan terjadi karena ada tanggung jawab.

d. Proses memilih pasangan.

Kesalahan dalam memilih pasangan hidup dapat berakibat fatal dalam perkawinan. Jika dalam memilih pasangan hidup tidak memperhatikan bagaimana rasa tanggung jawab pasangan nantinya terhadap perkawinan maka tingkat penyesuaian perkawinan akan rendah.

e. Karakteristik demografi yang dimiliki suami atau istri.

Karakteristik demografi yang memiliki hubungan yang cukup signifikan dengan penyesuaian perkawinan antara lain adalah pendapatan 
keluarga, pekerjaan, urutan kelahiran, jumlah saudara yang berlainan jenis kelamin, popularitas semasa remaja, perbedaan umur antara suami dengan istri, usia perkawinan, agama dan tingkat pendidikan suami/istri.

Hal yang cukup menarik dari uraian Schneiders adalah bahwa kedewasaan, tingkat kestabilan emosi dan rasa aman yang dimiliki seseorang akan mempengaruhi penyesuaian perkawinan. Menurut Landis \& Landis (1963) orang yang matang atau dewasa adalah orang yang dapat menyelesaikan masalah dengan baik, memahami motivasi manusia, dapat berpikir mandiri, bertanggung jawab terhadap kesalahan yang telah dilakukan, dapat menahan keinginan, dan siap untuk berkorban. Orang yang memiliki kemampuan-kemampuan tersebut adalah orang yang memiliki kecerdasan emosional yang tinggi, sehingga dapat dikatakan bahwa kecerdasan emosional juga merupakan salah satu faktor dari dalam individu yang mempengaruhi penyesuaian perkawinan. Hal ini juga telah disebutkan oleh Goleman (1995) bahwa kecerdasan emosional memiliki peranan dalam perkawinan, termasuk dalam penyesuaian perkawinan.

Wilson dkk (1997) mengemukakan bahwa dilihat dari perspektif atau sudut pandang ekosistemik, penyesuaian perkawinan dapat dipengaruhi oleh faktor demogafi (jenis kelamin, umur ketika menikah dan penghasilan keluarga), faktor dari dalam diri individu (kesehatan fisik, kesehatan emosional, dan stress) dan faktor keluarga (jumlah anggota keluarga dan problem yang dihadapi).
Sejalan dengan pendapat Wilson, Bradbury dkk (2000) menyatakan bahwa secara umum ada dua hal yang harus diperhatikan dalam memahami perkawinan, yaitu proses interpersonal antara suami dengan istri (meliputi kognisi, afeksi, fisiologi, dukungan sosial, kekerasan fisik) dan faktor ekologis (meliputi keberadaan anak, karakteristik dan latar belakang pasangan, kondisi yang dapat menimbulkan stress, ras, agama, keadaan sosial ekonomi lingkungan tempat tinggal).

\section{POLA PENYESUAIAN PERKAWINAN}

Banyak hal yang harus disesuaikan dalam perkawinan, seperti hubungan seksual, masalah keuangan, agama, aktivitas sosial \& rekreasi, hubungan dengan keluarga dari pasangan, hubungan dengan teman, dan cara mengasuh anak. Tidak jarang terjadi konflik antar pasangan suami istri agar hal-hal mendasar tersebut dapat disesuaikan. Menurut Landis \& Landis (1963) berdasarkan cara memecahkan konflik-konflik dalam perkawinan, ada tiga pola penyesuaian perkawinan.

Pola yang pertama adalah kompromi (compromise), yang berarti bahwa dalam memecahkan konflik pasangan suami-istri melakukan kesepakatan-kesepakatan yang memuaskan kedua belah pihak. Suami istri berusaha untuk menyatukan pendapat. Melalui kesepakatan, pasangan suami-istri meraih tingkat penyesuaian perkawinan yang tinggi yang kemudian menumbuhkan rasa saling percaya dan rasa aman. Pada tingkat penyesuaian perkawinan yang tinggi, baik 
suami maupun istri tidak merasa telah melakukan pengorbanan yang besar dalam mencapai kesepakatan.

Pola penyesuaian perkawinan yang kedua adalah akomodasi (accommodate). Pada pola ini, pasangan berada pada posisi yang bertolak belakang, memiliki karakteristik yang bertolak belakang, tetapi menerima kenyataan bahwa ada perbedaan. Pasangan suami-istri melakukan akomodasi untuk mencapai keseimbangan dengan mentoleransi tingkah laku atau hal-hal lain dari pasangannya yang berbeda dengannya. Selama proses akomodasi pasangan dapat melakukan diskusi untuk meraih cara pandang yang menguntungkan kedua belah pihak.

Pola penyesuaian yang ketiga adalah permusuhan (hostility). Pada pola ini pasangan suami-istri berusaha untuk tetap mempertahankan pendapat masing-masing dengan segala cara. Pasangan sering bertengkar dan cekcok mengenai berbagai hal yang berbeda. Pasangan suami-istri tidak dapat menyelesaikan perbedaan yang ada dengan cara yang memuaskan, sehingga perkawinan diliputi oleh tekanan.

\section{TIPE PERKAWINAN}

\section{BERDASARKAN PENYESUAIAN PERKAWINAN}

Penelitian mengenai penyesuaian perkawinan telah banyak dilakukan, terutama di luar negeri. Salah satu di antaranya adalah penelitian yang dilakukan oleh Cuber \& Harroff (Dyer, 1983) yang meneliti mengenai penyesuaian perkawinan dengan tujuan untuk melakukan pendefinisian kembali dan mendinamiskan konsep penyesuaian perkawinan. Berdasarkan hasil penelitian yang telah dilakukan, peneliti mengidentifikasi bahwa setidaknya ada lima tipe perkawinan berdasarkan penyesuaian perkawinan. Kelima tipe perkawinan tersebut adalah sebagai berikut.

a. Perkawinan yang diliputi oleh konflik (Conflict-habituated relationships).

Pada tipe ini, perkawinan diliputi oleh tekanan dan konflik yang terus menerus setiap harinya, meskipun pasangan suami-istri sangat menjaganya dalam kontrol. Pertengkaran sering terjadi, tetapi tidak memperlihatkannya pada orang luar, sehingga dari luar mereka terlihat sangat rukun. Perkawinan tetap dilanjutkan karena faktor kohesivitas.

b. Perkawinan yang terasa hambar (Devitalized relationships).

Pada perkawinan tipe ini, perkawinan terasa hambar, tidak menggairahkan, tetapi tidak terjadi banyak konflik. Pada tipe perkawinan ini tidak ada ancaman yang serius, tetapi hubungan suami-istri lemah atau suami-istri tidak saling menghiraukan dan sangat berbeda dengan ketika baru memasuki pintu gerbang perkawinan. Ada beberapa aspek yang masih memuaskan bagi pasangan suami-istri, yaitu berbagi minat mengenai anak, tradisi keluarga, dan kepemilikan bersama.

c. Perkawinan yang cukup nyaman (Passive-congenital relationships). Pada perkawinan tipe ini, pasangan suami istri merasa cocok dengan pasangannya, mereka berbagi aktivitas dan kesenangan, mereka merasa cukup nyaman dengan per- 
kawinan yang dijalankannya, tetapi aktivitas dan minat yang dilakukan bersama-sama bukan pada hal-hal yang vital atau penting dalam sebuah perkawinan.

d. Perkawinan yang menunjukkan suami-istri berbagi aktivitas pada hal-hal yang vital (Vital relationships).

Pada perkawinan tipe ini, pasangan suami-istri berbagi aktivitas dan minat yang vital (penting) dan menggairahkan, seperti mengasuh anak, mengerjakan hobi, ataupun melakukan hubungan seksual. Suami dan istri menganggap bahwa hubungan di antara mereka merupakan sesuatu yang penting, bersedia berkorban untuk dapat menjalin hubungan yang memuaskan dengan pasangannya.

e. Perkawinan yang menunjukkan adanya hubungan totalitas antara suami-istri (Total relationships).

Pada perkawinan tipe ini pasangan suami-istri berbagi minat dan aktivitas pada semua hal yang ada atau hadir dalam perkawinan. Pasangan suamiistri menjalin hubungan secara totalitas pada setiap hal yang ada dalam perkawinan. Perkawinan tipe ini adalah perkawinan yang sangat menggairahkan.

\section{KESIMPULAN}

Penyesuaian perkawinan merupakan hal yang harus dilakukan oleh pasangan suami-istri untuk menjaga keutuhan rumah tangga. Banyak hal yang perlu disesuaikan dalam perkawinan, antara lain adalah agama atau nilai-nilai, urusan rumah tangga, cara pengasuhan, masalah keuangan, masalah hubungan seksual, aktivitas sosial \& rekreasi, hubungan dengan keluarga dari pasangannya, dan hubungan dengan teman.

Sulitnya pasangan suami istri dalam melakukan penyesuaian perkawinan juga disebabkan oleh karakteristik manusia yang dapat berubah. Pasangan suami-istri akan menggunakan pola penyesuaian perkawinan yang dapat dibedakan menjadi tiga pola, yaitu pola kompromi, pola akomodasi, dan pola permusuhan. Berkaitan dengan penyesuaian perkawinan yang dilakukan oleh pasangan suami-istri, ada lima tipe perkawinan yang terbentuk, yaitu: conflict-habituated relationships, devitalized relationships, passivecongenital relationships, vital relationships, dan total relationships.

\section{DAFTAR PUSTAKA}

Ancok, D. 1993. Stress Rumah Tangga, Berakibat Tingginya Kekerasan Keluarga. Kedaulatan Rakyat. 22 Januari 1993.

BP4. 1991. Persiapan Menuju Perkawinan yang Lestari. Jakarta: Pustaka Antara.

Bradbury, T.N., Fincham, F.D. and Beach S.R.H. 2000. Research on The Nature and Determinants of Marital Satisfaction: A Decade in Review. Journal of Marriage and The Family. 62, 964-980.

Callhoun, J.F. and Acocella, J. R. 1990. Psychology of Adjustment and Human Relationships. New York: McGraw-Hill, Inc. 
Doi, A.R. 1992. Perkawinan Dalam Syariat Islam. Jakarta : PT Rineka Cipta.

Dyer, E.D. 1983. Courtship, Marriage and Family: American Style. Illinois: The Dorsey Press.

Goleman,, D. 1995. Emotional Intelligence. New York: Bantam Books.

Graham, C.W., Fischer, J.L., Crawford. D., Fitzpatrick, J., Kristan, B. 2000. Parental Status, Social Support, and Marital Adjustment. Joumal of Family Issues., 21, 888-905.

Hendrix, L. 1997. Quality and Equality in Marriage: A Cross-cultural View. Cross-Cultural Research, 31, 201-225.

Hurlock, E.B. 1993. Psikologi Perkembangan suatu Pendekatan Sepanjang Rentang Kehidupan. Alih Bahasa: Istiwidayanti, Soedjarwo, Sijabat R.M. Jakarta: Erlangga.

Kephart W.M., and Jedlicka, D. 1991. The Family, Society, and The Individual, $7^{\text {th }}$ Ed. New York: HarperCollins Publishers Inc.

Klein, D.M. 2000. Predicting Success or Failure in Marriage. Journal of Marriage and The Family, 62, 849-852.

Kowani. 1983. Pedoman Penyuluhan Undang-undang Perkawinan. Jakarta : BP 4 Pusat.
Landis, J.T. and Landis, M.G. 1963. Building A Successful Marriage. New York: Prentice Hall, Inc.

Lasswell, M. and Lasswell, T. 1987. Mamiage and The Family. Califomia: Woodsworth, Inc.

Papalia, D.E. and Old, S.W. 1995. Human Development. New York: McGraw Hill.

Sabiq, S. 1994. Fikih Sunah Jilid 7. Alih bahasa: Moh. Thalib.Bandung: AI Ma'arif.

Schneiders, A.A. 1955. Personal Adjustment and Mental Health. New York :Holt, Rinehart and Winston.

Syuqqoh, A. H. 1999. Kebebasan Wanita Jilid 5. Alih bahasa: As'ad Yasin.Jakarta: Gema Insani Press.

Wilson, S.M., Larson, J.H., McCulloch, B.J. and Stone, K.L. 1997. Dyadic Adjustment: An Ecosystemic Examination. The American Journal of Family Therapy. 25, 291-206. 